\title{
Glycinergic transmission in the mammalian retina
}

\author{
Heinz Wässle ${ }^{1 *}$, Liane Heinze ${ }^{1,2}$, Elena Ivanova ${ }^{1,3}$, Sriparna Majumdar ${ }^{1,4}$, Jan Weiss ${ }^{1,5}$, Robert J. Harvey \\ and Silke Haverkamp ${ }^{1}$
}

1 Department of Neuroanatomy, Max-Planck-Institute for Brain Research, Frankfurt, Germany

2 Ratiopharm GmbH, Ulm, Germany

3 Department of Anatomy and Cell Biology, Wayne State University, School of Medicine, Detroit, USA

4 Department of Ophthalmology, School of Medicine, University of California, San Francisco, USA

5 Physiological Institute, Universität des Saarlandes, Homburg/Saar, Germany

${ }^{6}$ Department of Pharmacology, The School of Pharmacy, University of London, London, UK

\section{Edited by:}

Jean-Michel Rigo, Universiteit Hasselt, Belgium

\section{Reviewed by:}

Dario Protti, The University of Sydney, Australia

Joe Lynch, Queensland Brain Institute, University of Queensland, Australia

\section{*Correspondence:}

Heinz Wässle, Max-Planck-Institute for Brain Research, Deutschordenstrasse 46, D-60528 Frankfurt/Main, Germany. e-mail:waessle@mpih-frankfurt.mpg.de
Glycine and $\gamma$-aminobutyric acid (GABA) are the major inhibitory neurotransmitters in the retina. Approximately half of the amacrine cells release glycine at their synapses with bipolar, other amacrine, and ganglion cells. Glycinergic amacrine cells are small-field amacrine cells with vertically oriented dendrites and comprise more than 10 different morphological types. The retinal distributions of glycine receptor (GlyR) $\alpha 1, \alpha 2, \alpha 3$ and $\alpha 4$ subtypes have been mapped with subunit-specific antibodies. GlyRs were clustered at postsynaptic hot spots which showed selective distributions for the different subunits. As a rule, only one $\alpha$ subunit was expressed at a given postsynaptic site. The kinetic properties of GlyRs were measured by recording spontaneous inhibitory postsynaptic currents (sIPSCs) from identified retinal neurons in wildtype, Glra 1spd-ot, Glra2 and Glra3 knockout mice. From observed differences of sIPSCs in wildtype and mutant mice, the cell-type specific subunit composition of GlyRs could be defined. OFF-cone bipolar cells and A-type ganglion cells receive prominent glycinergic input with fast kinetics that is mainly mediated by $\alpha 1 \beta$ GlyRs (decay time constant $\tau \sim 5 \mathrm{~ms}$ ). By contrast, All amacrine cells express $\alpha 3 \beta$ GlyRs with medium fast kinetics ( $\tau \sim 11 \mathrm{~ms}$ ). Narrow-field (NF) and wide-field amacrine cells contain predominantly $\alpha 2 \beta$ GlyRs with slow kinetics ( $\tau \sim 27 \mathrm{~ms}$ ). Lastly, ON-starburst, narrow-field and wide-field amacrine cells in Glra2knockout mice express $\alpha 4 \beta$ GlyRs with very slow kinetics ( $\tau \sim 70 \mathrm{~ms}$ ).

Keywords: glycine receptors, sIPSCs, retina, synapses, Glra $1^{\text {spd-ot }}$ mice, Glra2 ${ }^{-/-}$mice, Glra3 ${ }^{-/-}$mice $^{-1}$

\section{INTRODUCTION}

Glycine and GABA, the major inhibitory transmitters of the mammalian retina, are preferentially localized in different types of amacrine cells which fulfill specific roles in the processing of visual signals (Pourcho, 1996). GABA-ergic amacrine cells are widefield amacrine cells providing lateral interactions across the inner plexiform layer (IPL; Lin and Masland, 2006). They are involved in the generation of receptive field surrounds (Flores-Herr et al., 2001) and in the computation of direction selective light responses (Taylor and Vaney, 2003). Glycinergic amacrine cells are small-field cells, whose dendrites are primarily involved in local interactions between different sublaminas of the IPL, such as the OFF- and ON-sublamina (Hsueh et al., 2008).

Glycine has been localized in $40-50 \%$ of all retinal amacrine cells (Marc, 1989; Pourcho, 1996; Pow and Hendrickson, 1999), which exist in more than 10 distinct morphological types (Badea and Nathans, 2004; MacNeil and Masland, 1998; Menger et al., 1998; Vaney, 1990). They receive synaptic input from bipolar cells at ribbon synapses and from other amacrine cells - both GABAergic and glycinergic - at conventional chemical synapses. Their output synapses contact bipolar cells, other amacrine cells and ganglion cells (Jusuf et al., 2005; Pourcho and Owczarzak, 1991a,b; Sassoè-Pognetto et al., 1994). Some glycinergic amacrine cells bear interplexiform processes ascending towards the outer plexiform layer (OPL; Kolb and West, 1977).

The diversity of types of glycinergic amacrine cells is paralleled by the striking heterogeneity of glycine receptors (GlyRs). All four $\alpha$ subunits of the GlyR have been localized to specific synapses within the mammalian retina (Haverkamp et al., 2003, 2004; Heinze et al., 2007; Sassoè-Pognetto et al., 1994). To date, selective agonists or antagonists that distinguish different isoforms of synaptic GlyRs have not been identified (Betz and Laube, 2006; Harvey and Betz, 2000; Legendre, 2001; Lynch, 2004). However, mutant mice are available that have dysfunction of specific GlyR subunits and thus it became possible to study details of the glycinergic synaptic transmission in the mammalian retina (Ivanova et al., 2006; Majumdar et al., 2007; Weiss et al., 2008).

It has to be emphasized that the morphological types of glycinergic amacrine cells, their circuits, and the distribution of GlyRs are closely similar when different mammalian retinas are compared (Masland, 2001). In this review we concentrate on the mouse retina because mutants are available that express green fluorescent protein (GFP) in specific types of amacrine cells (Haverkamp et al., 2009; Heinze et al., 2007), and also mutants which lack specific GlyR subunits.

There are more than 10 different types of bipolar cells, at least 30 types of amacrine cells and approximately 15 types of ganglion 
cells in any mammalian retina (Masland, 2001). They are involved with different retinal circuits and fulfill specific roles in visual processing. In this review it will be shown that they express different sets of synaptic GlyRs.

\section{RESULTS}

\section{LOCALIZATION OF GLYCINE IN AMACRINE CELLS}

The first anatomical demonstration of glycine as neurotransmitter in the mammalian retina was through uptake of tritiated glycine followed by autoradiography (Ehinger and Falck, 1971). Amacrine cells were prominently demarcated, whilst some bipolar cells were weakly labelled. More recent demonstrations of glycine in the retina applied immunolabelling with antibodies against glycine or against the glycine transporter GlyT1 (Menger et al., 1998; Pow, 1998; Pow and Hendrickson, 2000). Figure 1 shows a vertical section through a mouse retina that was double immunolabelled for glycine and for GlyT1 (Haverkamp and Wässle, 2000). Strong glycine immunoreactivity can be observed in amacrine cell bodies and their dendrites descending into the IPL (Figure 1A). Weak glycine expression is also found in putative ON-cone bipolar cells in the centre of the inner nuclear layer (INL). The section was also immunolabelled for GlyT1 (Figure 1B) which labels all glycinergic amacrine cells but not bipolar cells (Figure 1C).

Bipolar cells do not express GlyT1 but they receive glycine by diffusion through electrical synapses (gap junctions) from glycinergic amacrine cells (Vaney et al., 1998). However, there is no evidence that bipolar cells release glycine in addition to L-glutamate, the well established transmitter released by bipolar cells. In other parts of the CNS, GlyT1 has been localized to glial cells, whilst GlyT2 is now known to represent the presynaptic neuronal glycine transporter (Zafra et al., 1995). Surprisingly, GlyT2 does not appear to be expressed in the mammalian retina (Zafra et al., 1995). Thus, uptake of tritiated glycine, glycine immunolabelling and GlyT1 expression all indicate that half of the amacrine cells of the mammalian retina are glycinergic (Marc and Liu, 1985; Pow and Hendrickson, 1999; Wässle et al., 1986) and that this is the main source of releasable glycine in the retina.

\section{MORPHOLOGICAL TYPES OF GLYCINERGIC AMACRINE CELLS}

The most prominent and also most numerous glycinergic amacrine cell is the AII amacrine cell which transfers the light signal from rod bipolar cells into the cone pathway (Kolb and Famiglietti, 1974). Figure 2A shows the typical bistratified morphology of a neurobiotin injected AII amacrine cell from the mouse retina and Figure 2B shows the dense array of AII cells immunostained for parvalbumin in the rat retina. In the outer IPL, AII cell lobular dendrites provide glycinergic, chemical output synapses onto OFFcone bipolar cell axon terminals. In the inner IPL, AII cells receive input from rod bipolar cells and are engaged via electrical synapses (gap junctions) with ON-cone bipolar cell axon terminals. Further glycinergic, small-field amacrine cells were identified in the cat retina by combined Golgi-staining and glycine uptake (Pourcho, 1980; Pourcho and Goebel, 1985). In a systematic survey, Menger et al. (1998) identified at least eight different glycinergic amacrine cells in the rat retina. More recent studies on glycinergic amacrine cells in the retina have utilised a transgenic mouse (GFP-O) which expresses green fluorescent protein (GFP) under the control of the thy-1 promoter (Feng et al., 2000; Heinze et al., 2007). Five
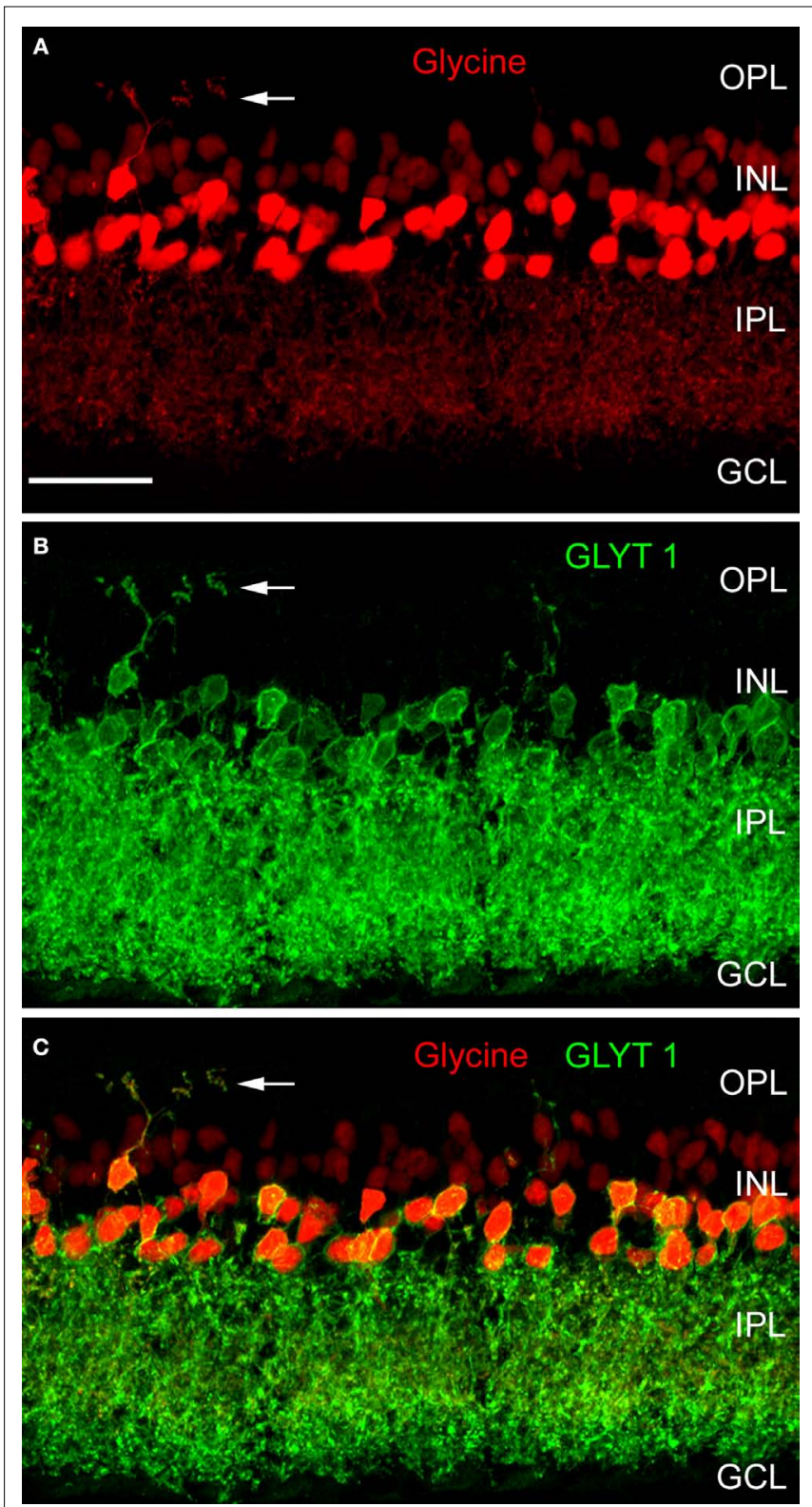

FIGURE 1 | Glycinergic amacrine cells of the mouse retina (modified from Haverkamp and Wässle, 2000). A vertical section was double immunolabelled for glycine (red) and the glycine transporter GlyT1 (green). (A) Strong glycine immunofluorescence is found in amacrine cells at the INL/IPL border. Weak glycine immunofluorescence is also present in the cell bodies of ON-cone bipolar cells in the center of the INL. (B) GlyT1 immunofluorescence is found in amacrine cell bodies and their dendrites descending into the IPL. (C) The superposition of (A) and (B) shows that only the amacrine cells but not the bipolar cells express GlyT1. The arrows indicate an interplexiform process ascending to the OPL (OPL: outer plexiform layer; INL: inner nuclear layer; IPL: inner plexiform layer; GCL; ganglion cell layer; Scale bar: $25 \mu \mathrm{m})$.

such cells are illustrated in Figures 2C-G, with double labelling for calretinin in order to reveal the different sublaminas of the IPL. Although they are all small-field amacrine cells, the level of stratification of their dendrites within the IPL is clearly different. The cells in Figures 2C-E have small, diffuse dendritic trees confined to the outer, middle and inner IPL, respectively. By contrast, 


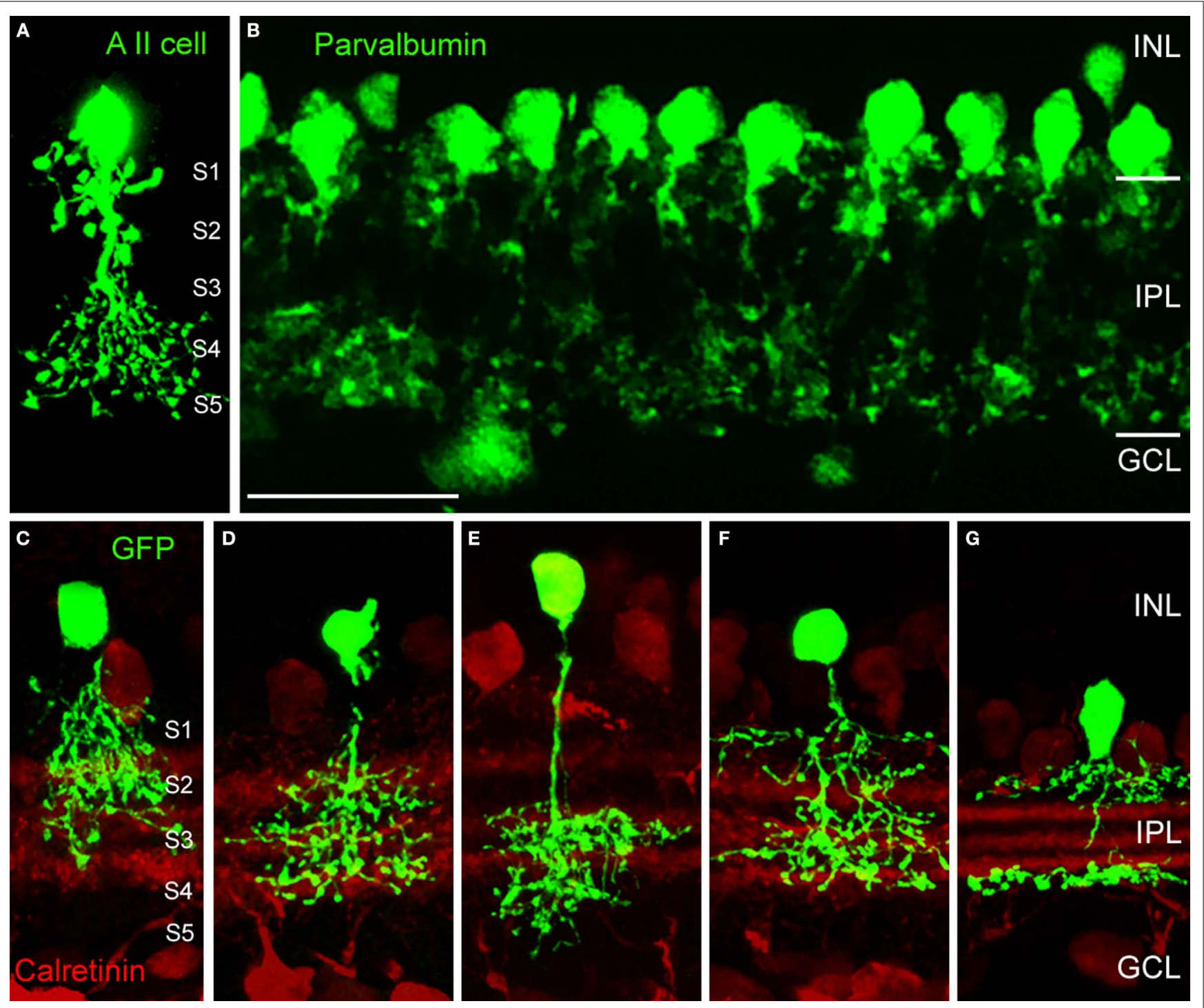

FIGURE 2 | Morphological types of glycinergic amacrine cells (modified from Heinze et al., 2007; Weiss et al., 2008). (A) Vertical section of an All amacrine cell of the mouse retina that was filled with neurobiotin during patch-clamp recordings. The IPL is subdivided into 5 sublaminas of equal thickness. (B) The array of All amacrine cells of the rat retina immunostained for parvalbumin (Scale bar: $25 \mu \mathrm{m})$. (C-G) Glycinergic amacrine cells expressing GFP (green fluorescent protein) in the thy1-GFP-O mouse (Feng et al., 2000). (C) Type 2 cell. (D) Type 3 cell. (E) Type 4 cell. (F) Type 7 cell (all according to the scheme of Menger et al., 1998). (G) A8 cell (according to Kolb et al., 1981). the cells in Figures 2F,G have a bistratified appearance. More than 10 distinct types of glycinergic amacrine cells have been identified from such morphological criteria (MacNeil and Masland, 1998) and more may be found in future studies.

\section{SYNAPTIC LOCALIZATION OF GLYCINE RECEPTORS}

The postsynaptic glycine receptor (GlyR) is a ligand-gated chloride channel composed of ligand-binding $\alpha$ and $\beta$ subunits. The $\beta$ subunits bind to the receptor clustering protein gephyrin (reviewed by Harvey and Betz, 2000; Legendre, 2001; Lynch, 2004; Vannier and Triller, 1997). Molecular cloning has revealed four genes encoding the $\alpha$ subunits $(\alpha 1, \alpha 2, \alpha 3, \alpha 4)$ and only one gene encoding the $\beta$ subunit (Harvey et al., 2000). In the adult two copies of the $\alpha$ subunit and three copies of the $\beta$ subunit form the pentameric receptor protein (Grudzinska et al., 2005). Subunit selective antibodies have recently become available that recognize the four GlyR $\alpha$ subtypes (Harvey et al., 2004; Haverkamp et al., 2003, 2004; Heinze et al., 2007). When these antibodies were applied to lightly fixed sections of the mammalian retina, they each produce a distinct punctate immunofluorescence pattern (Figure 3). Electron microscopy has suggested that these puncta represent clusters of GlyRs at postsynaptic sites (Figure 3B; Sassoè-Pognetto et al., 1994). The GlyR $\alpha 1$ subunit is expressed in a sparse population of puncta in the OPL, which represent synapses between glycinergic interplexiform processes and bipolar cell dendrites (Figures 3A,C). In the outer IPL (stratum S1 and S2) GlyR $\alpha 1$ immunoreactivity is found in large puncta, which 

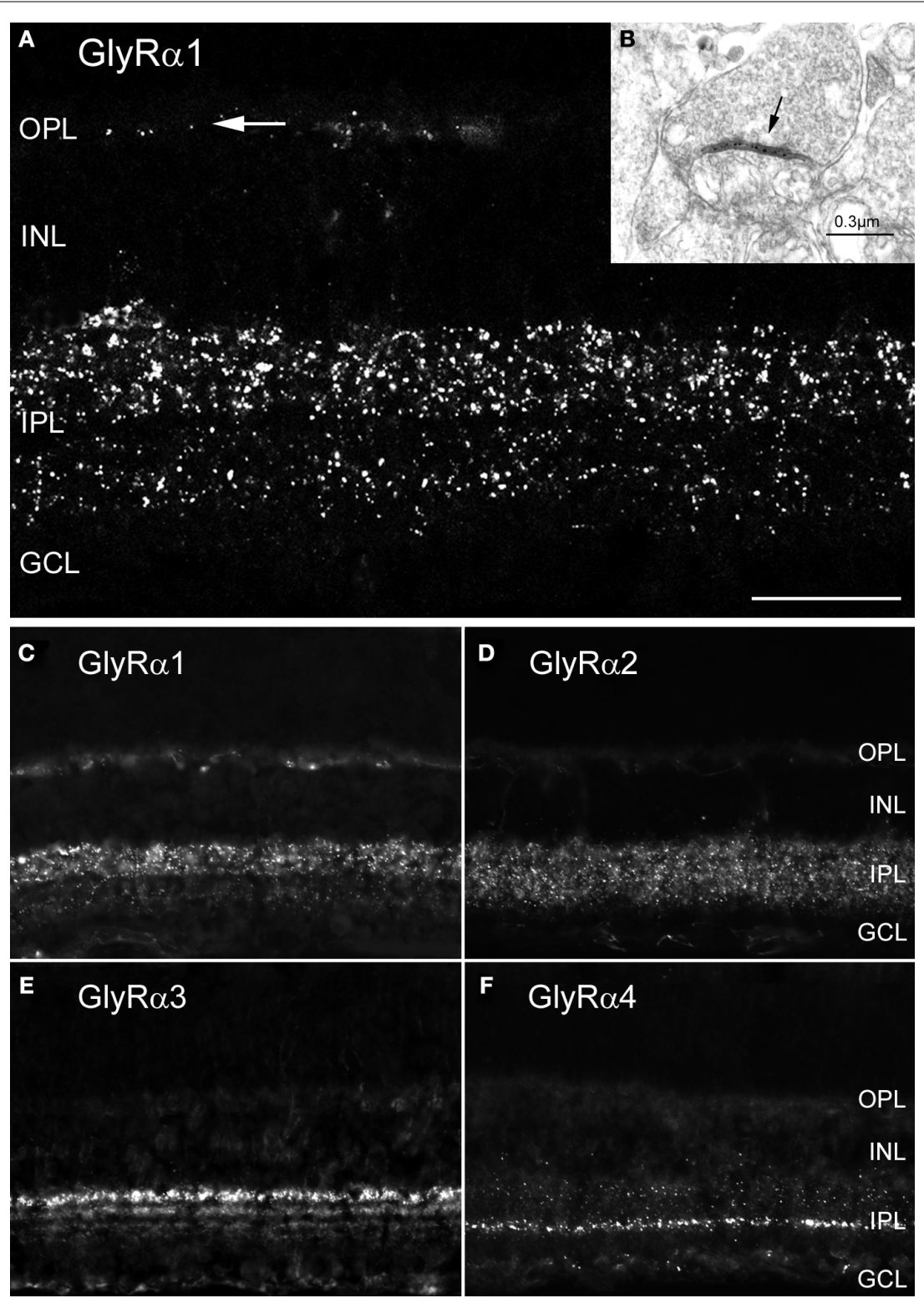

FIGURE 3 | Synaptic localization of GlyR subtypes in the rodent retina (modified from Heinze et al., 2007; Sassoè-Pognetto et al., 1994).

(A) Fluorescence micrograph of a vertical section through a rat retina that was immunostained for the GlyR $\alpha 1$ subunit. The arrow points to a few synaptic clusters in the OPL. (B) Electron micrograph showing a synapse (arrow) expressing the GlyR $\alpha 1$ subunit. The antibody (mAb2b) recognises an extracellular epitope and, therefore, the synaptic cleft is immunolabelled. (C-F) Vertical sections through the mouse retina. (C) GlyR $\alpha 1$ immunoreactive puncta are most prominent in the outer IPL. (D) GlyR $\alpha 2$ immunofluorescence is more evenly distributed across the IPL. (E) GlyR $\alpha 3$ expression is found in four bands. (F) GlyR $\alpha 4$ immunoreactivity is most prominent in a small band at the sublamina 3/4 border [Scale bar: $25 \mu \mathrm{m}$ in (A); $65 \mu \mathrm{m}$ in (C-F)]. occur at high density. They represent synapses between AII amacrine cells and OFF-cone bipolar cells (Sassoè-Pognetto et al., 1994). In the inner IPL (stratum S3-S5) smaller GlyR $\alpha 1$ immunoreactive puncta can be observed representing synapses onto ganglion cell dendrites and rod bipolar cell axons (Ivanova et al., 2006; Majumdar et al., 2007). The GlyR $\alpha 2$ subunit is more uniformly distributed across stratum 1-4 (Figure 3D), and GlyR $\alpha 2$ immunoreactive puncta occur at the highest density amongst the four $\alpha$ subunits (Haverkamp et al., 2004). The GlyR $\alpha 3$ subunit (Figure 3E) shows four bands of higher density of puncta (Haverkamp et al., 2003).
Lastly, the GlyR $\alpha 4$ subunit (Figure 3F) shows a band of high density of puncta at the border between stratum 3 and 4 (Heinze et al., 2007). This characteristic distribution of subunits across the IPL suggests that the GlyR subtypes are expressed at different synapses and are involved with different neuronal circuits.

\section{CO-LOCALIZATION OF GLYR SUBUNITS AT POSTSYNAPTIC SITES}

Since synaptic GlyRs are composed of $2 \alpha$ and $3 \beta$ subunits (Grudzinska et al., 2005) there is the possibility of two different $\alpha$ subunits co-existing in a single heteromeric GlyR. In addition, it 
is possible that two different GlyR subtypes, such as $\alpha 2 \beta$ and $\alpha 3 \beta$ GlyRs, co-distribute at the same postsynaptic sites. In both cases, the immunoreactive hot spots should coincide. However, when retinal sections were double labelled for the GlyR $\alpha 1$ subunit and the other three GlyR $\alpha$ subunits, no statistically significant coincidence rate of immunoreactive puncta was observed (Figures 4A-C). When retinal sections were double labelled for the GlyR $\alpha 2$ and $\alpha 3$ subunits a coincidence rate of $26.7 \%$ was found (Haverkamp et al., 2004). In retinal sections double labelled for the GlyR $\alpha 3$ and $\alpha 4$ subunits no significant coincidence rate was found (Heinze et al., 2007). In sections double labelled for the GlyR $\alpha 4$ and $\alpha 2$ subunits, $31.5 \%$ of the $\alpha 4$ immunoreactive clusters also contained the $\alpha 2$ subunit (Figures 4D-F). The results indicate that - as a rule - postsynaptic GlyR clusters contain only one type of $\alpha$ subunit. The exception is approximately one-third of synapses immunoreactive for GlyR $\alpha 2$ that can also contain the $\alpha 3$ or the $\alpha 4$ subunits.

\section{EXPRESSION OF GLYRS BY IDENTIFIED NEURONS}

In order to reveal the involvement of selected GlyR subtypes with different retinal circuits, identified neurons were immunostained for the different GlyR $\alpha$ subunits. Figure 5A shows an EGFP labelled
A-type ganglion cell in a whole mount of the thy-1 GFP-O mouse retina (Majumdar et al., 2007). The retina was also immunolabelled for the GlyR $\alpha 1$ subunit (Figure 5B) demonstrating that many GlyR $\alpha 1$ immunoreactive puncta decorate the dendrites of this A-type ganglion cell. This suggests the cell receives glycinergic input through synapses that contain the GlyR $\alpha 1$ subunit. A-type ganglion cells were also double labelled for the other $\alpha$ subunits (data not shown), and a small number of puncta coincided with the A-type dendrites. Quantification of these results showed that the predominant input is through GlyR $\alpha 1$ containing synapses. However, there is also a small but significant input through synapses expressing the other GlyR $\alpha$ subunits (Majumdar et al., 2007).

Double labelling approaches also enable the identification of the presynaptic partner of synaptic GlyRs in the retina. Figure 5C shows a vertical view of a Type 3 , glycinergic amacrine cell in the thy-1 GFP-O mouse retina. A single optical section through this EGFP-expressing cell together with GlyR $\alpha 2$ immunostaining is shown in Figure 5D. Many GlyR $\alpha 2$ immunoreactive puncta coincide with dendritic varicosities of the Type 3 cell. Since this cell is a glycinergic amacrine cell, the puncta may represent input synapses the cell receives from other, glycinergic amacrine cells or output
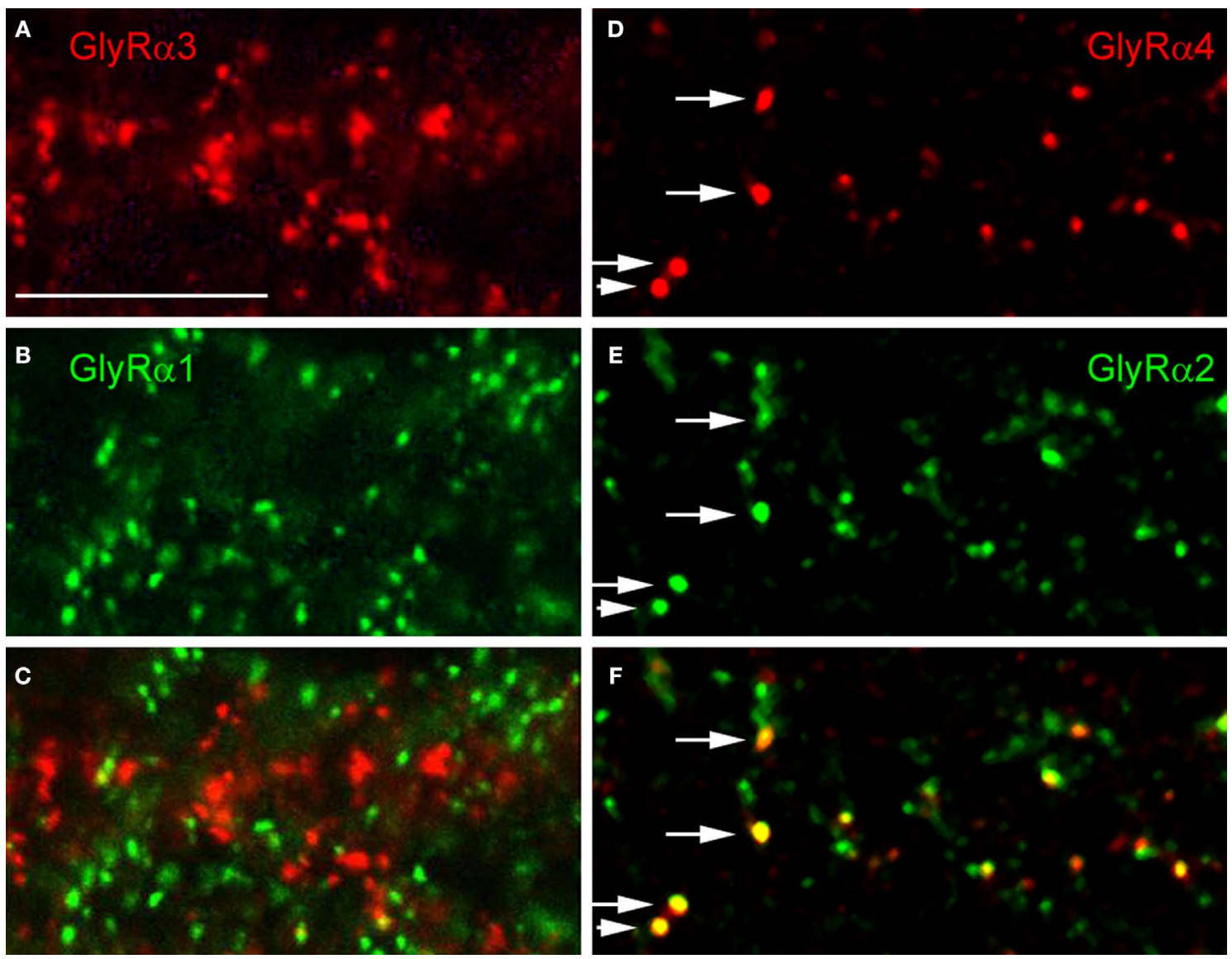

FIGURE 4 | Colocalization of GlyR subunits at postsynaptic sites (modified from Haverkamp et al., 2003; Heinze et al., 2007). (A) GlyR $\alpha 3$ immunoreactive puncta. (B) Same section as in (A), immunostained for GlyR $\alpha 1$. (C) Superposition of (A) and (B) shows that GlyR $\alpha 3$ and GlyR $\alpha 1$ immunoreactive puncta are not colocalized. (D) GlyR $\alpha 4$ immunoreactive puncta. (E) Same section as in (D), immunostained for GlyR $\alpha 2$. (F) superposition of (D) and (E) shows that GlyR $\alpha 2$ and GlyR $\alpha 4$ immunoreactive puncta sometimes colocalize (arrows). (Scale bar: $10 \mu \mathrm{m})$. 

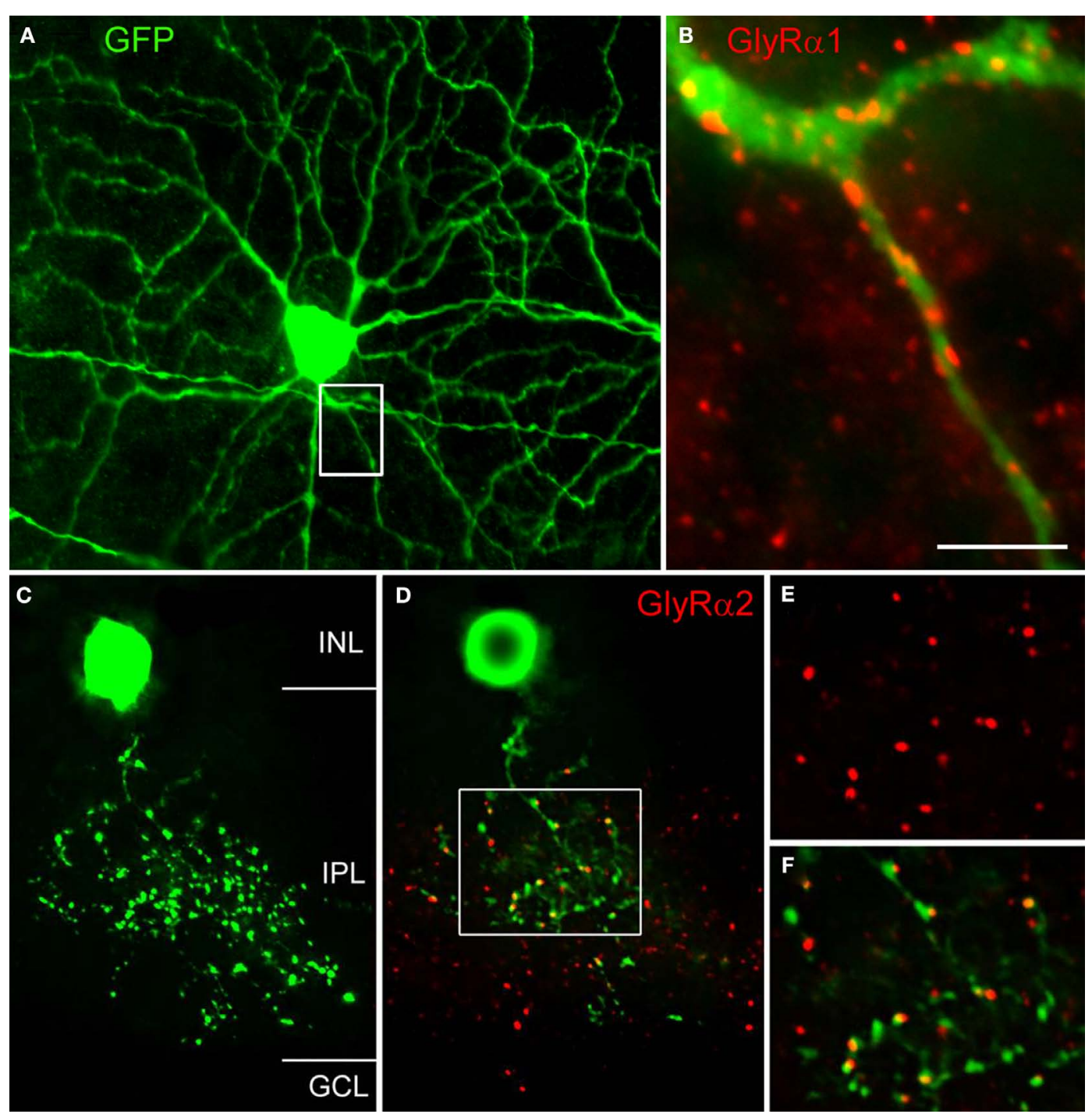

FIGURE 5 | Expression of GlyRs by identified neurons (modified from Majumdar et al., 2007). (A) This A-type ganglion cell expressed EGFP in a whole mount of the thy1 GFP-O mouse (Feng et al., 2000). The whole mount was also immunostained for GlyR $\alpha 1$. (B) The boxed area from $(\mathbf{A})$ is shown at higher magnification and the dendrite of the A-type ganglion cell is decorated by GlyR $\alpha 1$ immunoreactive puncta. (C) Vertical view of a Type 3 amacrine cell from the thy1 GFP-O mouse retina (collapsed stack of confocal sections). (D) Single confocal section of the cell in (C) also immunostained for the GlyR $\alpha 2$ subunit. The boxed area is shown at higher magnification in (E) and (F). (E) GlyR $\alpha 2$ immunoreactive puncta. (F) Dendritic varicosities and GlyR $\alpha 2$ immunoreactive puncta superimposed [Scale bar: $60 \mu \mathrm{m}$ in (A), $10 \mu \mathrm{m}$ in (B), $17 \mu \mathrm{m}$ in (C) and (D), $10 \mu \mathrm{m}$ in (E) and (F)]. synapses the cell makes onto other, non-labelled neurons. As can be seen from the magnified micrographs in Figures 5E,F, the red GlyR $\alpha 2$ immunoreactive puncta are always slightly displaced from the green varicosities. We interpret this result as indicating synaptic GlyR $\alpha 2$ clusters which are expressed by unknown neurons that are postsynaptic to this Type 3 cell.

The two examples of cells presented in Figure 5 suggest a correlation between the morphological type of a given neuron and the molecular signature of the glycinergic synapse it receives or makes. In this context one interesting question is whether the presynaptic neuron instructs the postsynaptic cell to express certain GlyR subunits or whether a given postsynaptic neuron expresses an exclusive GlyR subtype. We addressed this question by carrying out a detailed physiological characterisation of selected synaptic GlyRs.

\section{GLYCINE RECEPTORS EXPRESSED BY BIPOLAR CELLS}

Bipolar cells receive glutamatergic, synaptic input from photoreceptors in the OPL and provide synaptic output onto ganglion and amacrine cells in the IPL. Bipolar cell axons in the IPL receive synaptic input from both GABAergic and glycinergic amacrine cells. There are about 10 different types of cone bipolar (CB) and one rod bipolar (RB) cell in the mammalian retina (reviewed by Wässle et al., 2009). The major subdivision is into OFF- and ONCB cells, which are hyperpolarized and depolarized, respectively, by a light stimulus. RB cells are ON bipolar cells. Axons of OFF-CB 
cells terminate in the outer half of the IPL, those of ON-CB and RB cells in the inner half (Wässle, 2004).

Patch-clamp recordings performed from bipolar cells in slices of the mouse retina (Ivanova et al., 2006) enabled the study of GlyRs by the application of exogenous glycine, and by recording and analyzing glycinergic spontaneous inhibitory postsynaptic currents (IPSCs) in the presence and absence of selected antagonists. The patch electrode was filled with a solution containing neurobiotin and Alexa 488 which diffused into the bipolar cells during the recordings. The slices were immunostained after the experiments and thus the bipolar cell type could be identified unequivocally. The glycinergic IPSCs measured in wild-type mouse retinas were also compared with those from two mutant mouse retinas, one deficient in the GlyR $\alpha 1$ subunit (Glra1 ${ }^{\text {spd-ot }}$, "oscillator", Buckwalter et al., 1994; Kling et al., 1997) and one deficient in the GlyR $\alpha 3$ subunit (Glra3 ${ }^{-1-}$, Harvey et al., 2004; Haverkamp et al., 2003). Mice deficient in the GlyR $\alpha 3$ subunit did not show an apparent phenotype (Harvey et al., 2004; Haverkamp et al., 2003). Homozygous Glral ${ }^{\text {spd-ot }}$ mice die at about 3 weeks of age (Buckwalter et al., 1994) and juvenile Glra1 ${ }^{\text {spd-ot }}$ mice, of the age of 16-18 days, were used for the experiments. The results were compared to measurements in wildtype mice of the same age.

The exogenous application of glycine elicited large-amplitude glycinergic currents in all OFF-CB and RB cells, whilst ON-CB cells exhibited only very small, if any, glycinergic currents (Eggers and Lukasiewicz, 2006; Ivanova et al., 2006). Co-application of the selective GlyR antagonist strychnine $(3 \mu \mathrm{M})$ blocked these glycine-induced currents as expected. Wang and Slaughter (2005) have also shown that the $\mathrm{GABA}_{\mathrm{A}}$ receptor antagonists bicuculline and gabazine are also competitive antagonists of homomeric $\alpha 1$ and $\alpha 2$ subunit GlyRs expressed in HEK293 cells or on retinal neurons at high micromolar $\mathrm{IC}_{50}$ s. However, glycine-induced currents recorded from bipolar cells were not affected by either bicuculline $(100 \mu \mathrm{M})$ or gabazine $(3 \mu \mathrm{M})$ (Ivanova et al., 2006). It has also been reported (Han et al., 2003) that DCKA (5,7 dichlorokynurenic acid), an antagonist of the glycinebinding site of NMDA receptors, blocks the slowly desensitizing glycine-induced current in the tiger salamander retina. Picrotoxinin is also a specific blocker of GlyRs in recombinant expression systems (Pribilla et al., 1992). Application of picrotoxinin $(50 \mu \mathrm{M})$ reduced the peak currents in bipolar cells to $93 \%$ but application of DCKA $(500 \mu \mathrm{M})$ did not inhibit glycine-induced currents on bipolar cells. These results suggest that bicuculline, gabazine, picrotoxinin and DCKA are not useful pharmacological tools for differentiating the types of GlyRs expressed by bipolar cells.

Studies using knockout mice were more revealing. While there was no significant difference between glycine-induced currents from bipolar cells in wild-type and $\mathrm{Glra}^{-1-}$ mice, glycine-induced currents could not be elicited in any bipolar cell in oscillator mice ( $G l r a 1^{\text {spd-ot }}$ ) even when glycine was applied at a concentration as high as $10 \mathrm{mM}$. A more detailed analysis of bipolar cell GlyRs involved the study of sIPSCs. Figure 6A shows a recording of spontaneous IPSCs (sIPSCs) from an OFF CB cell at low temporal resolution. When $\mathrm{GABA}_{\mathrm{A}} \mathrm{R}(3 \mu \mathrm{M}$ gabazine $)$ and the $\mathrm{GABA}_{C} \mathrm{R}(100 \mu \mathrm{M}$ TPMPA) antagonists were applied (Figure 6A, 2) sIPSCs remained and the frequency was slightly increased. However, when strychnine was co-applied with both GABAR antagonists (Figure 6A, 3) the

\section{A}

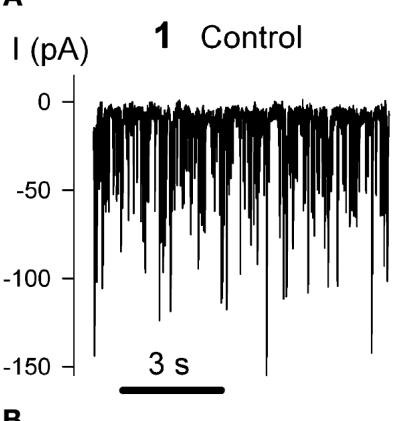

B

I (pA)

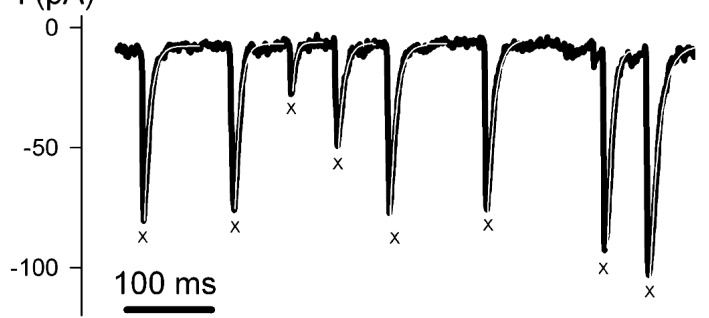

FIGURE 6 | Recordings of spontaneous IPSCs from OFF-CB cells of the mouse retina (modified from Ivanova et al., 2006). (A) At a holding potential of $V_{H}=-50 \mathrm{mV}$, large sIPSCs were recorded (1). Co-application of the GABAR antagonists gabazine and TPMPA (1,2,5,6 tetrahydrpyridine-4-y-

methylphosphonic acid) did not block the IPSCs (2). However, co-application of GABAR antagonists and strychnine (Stry) abolished the IPSCs (3). (B) IPSCs
$2 \begin{array}{r}3 \mu \mathrm{M} \text { Gabazine } \\ +100 \mu \mathrm{M} \text { TPMPA }\end{array}$

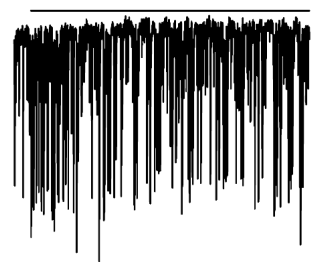

C

Events (\%)

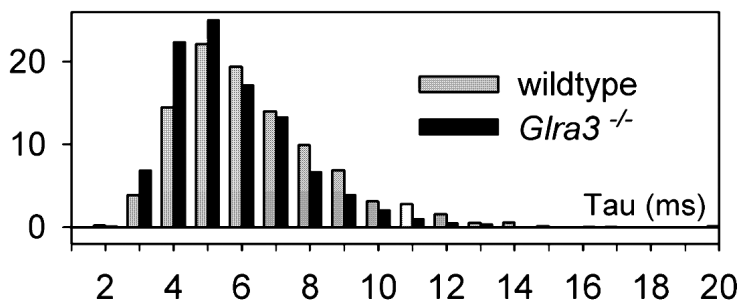

from trace 2 in (A) are shown at higher temporal resolution. IPSCs with monotonic rising and decay phase are marked by $X$ and their decay phase was approximated by a single exponential function with the time constant $\tau$ (white lines superimposed on black traces). (C) The histogram represents the relative frequencies calculated from 17 cells recorded in wild-type mice (light bars), and 15 cells recorded from Glra3 ${ }^{-1-}$ mice (dark bars) 
sIPSCs completely disappeared, demonstrating that they represent glycinergic sIPSCs. The trace in Figure 6B shows the IPSCs at higher magnification, enabling the kinetics of single sIPSCs to be analysed. Superimposed events were excluded from the analysis, and only those with monotonic rising phase, lacking inflections and returning to the baseline without contamination from subsequent events were selected (marked by X in Figure 6B). We found that the decay phase could be described by a single exponential function with a decay time constant $\tau$. In a total of 17 OFF CB cells studied in retinal slices from wild-type mice, the sIPSCs had a mean amplitude of $-70 \pm 38 \mathrm{pA}$, a mean rise time of $1.1 \pm 0.3 \mathrm{~ms}$ and a mean decay time constant $\tau=5.9 \pm 1.4 \mathrm{~ms}$ (total number of OFF CB cells $n=17$, total number of IPSCs analysed: $N=2296$ ). Glycinergic sIPSCs were also recorded from OFF-CB cells in retinal slices from $\mathrm{Glra3}^{-/-}$mice. The IPSCs had a mean amplitude of $-81.9 \pm 34 \mathrm{pA}$, a mean rise time of $1.1 \pm 0.2 \mathrm{~ms}$ and a mean decay time constant $\tau=5.1 \pm 1.0 \mathrm{~ms}(n=15, N=3273)$. The histogram in Figure $6 \mathrm{C}$ compares the decay time constants of glycinergic IPSCs recorded from wild-type and $\mathrm{Glra}^{-/-}$mice. No significant difference between the two distributions was found (Kolmogorov-Smirnov test, $p>0.05)$. The result suggests that the GlyR $\alpha 3$ subunit is not an essential component of GlyRs on OFF-CB cells. We also recorded 17 OFF-CB cells from the retinas from Glra ${ }^{\text {spd-ot }}$ mice, and did not observe glycine-induced currents or glycinergic sIPSCs. By contrast, amacrine and ganglion cells in Glra $1^{\text {spd-ot }}$ mice showed both glycine responses and glycinergic sIPSCs (Majumdar et al., 2007; Weiss et al., 2008). The total lack of glycine responses in Glral ${ }^{\text {spd-ot }}$ mice suggests that the GlyR $\alpha 1$ subunit is an essential component of GlyRs on OFF CB cells.

\section{GLYCINE RECEPTORS ON AII AND NARROW-FIELD AMACRINE CELLS}

Glycinergic amacrine cells comprise at least 10 different morphological types (Figure 2). The GlyRs expressed by AII amacrine cells and by the narrow-field (NF) amacrine cells Types 5/6 and Type 7 (Menger et al., 1998) were studied by patch-clamp recordings in mouse retinal slices. During the recordings, the cells were filled with a fluorescent marker (Figures 7A) to aid morphological identification. Application of exogenous glycine induced $\mathrm{Cl}^{-}$-currents both in AII and NF amacrine cells that were blocked by the coapplication of strychnine $(3 \mu \mathrm{M})$ and reduced by the co-application

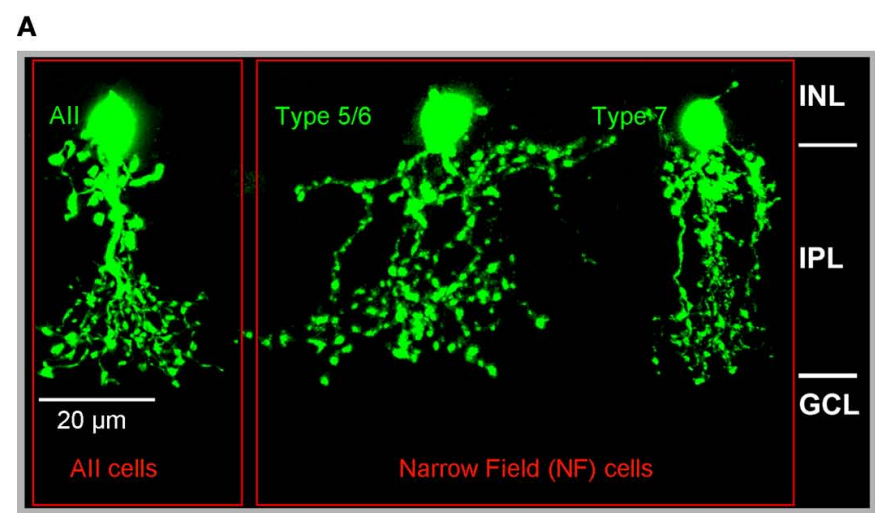

B

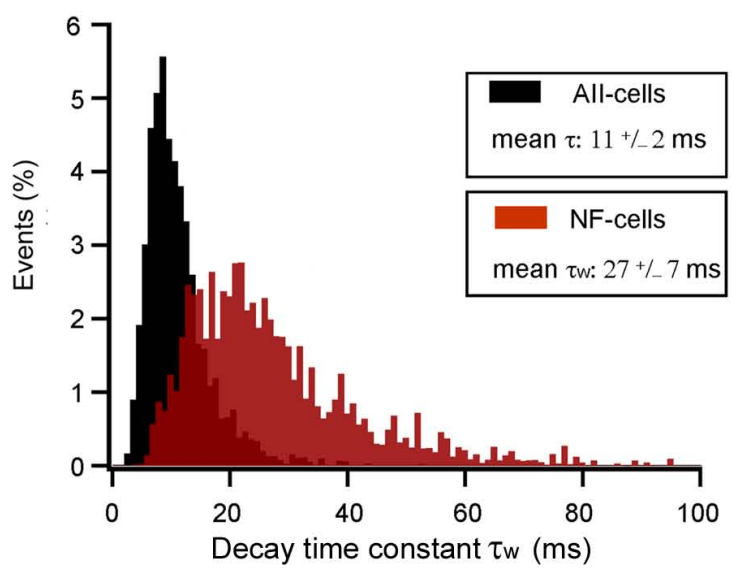

FIGURE 7 | Glycinergic sIPSCs of small-field amacrine cells of the mouse retina (modified from Weiss et al., 2008). (A) Collapsed stack of confocal sections through an All amacrine cell (left), a Type 5/6 cell (center) and a Type 7 cell (right). They are referred to as narrow-field (NF) amacrine cells. (B) Frequency histogram of decay time constants of glycinergic sIPSCs recorded from All cells

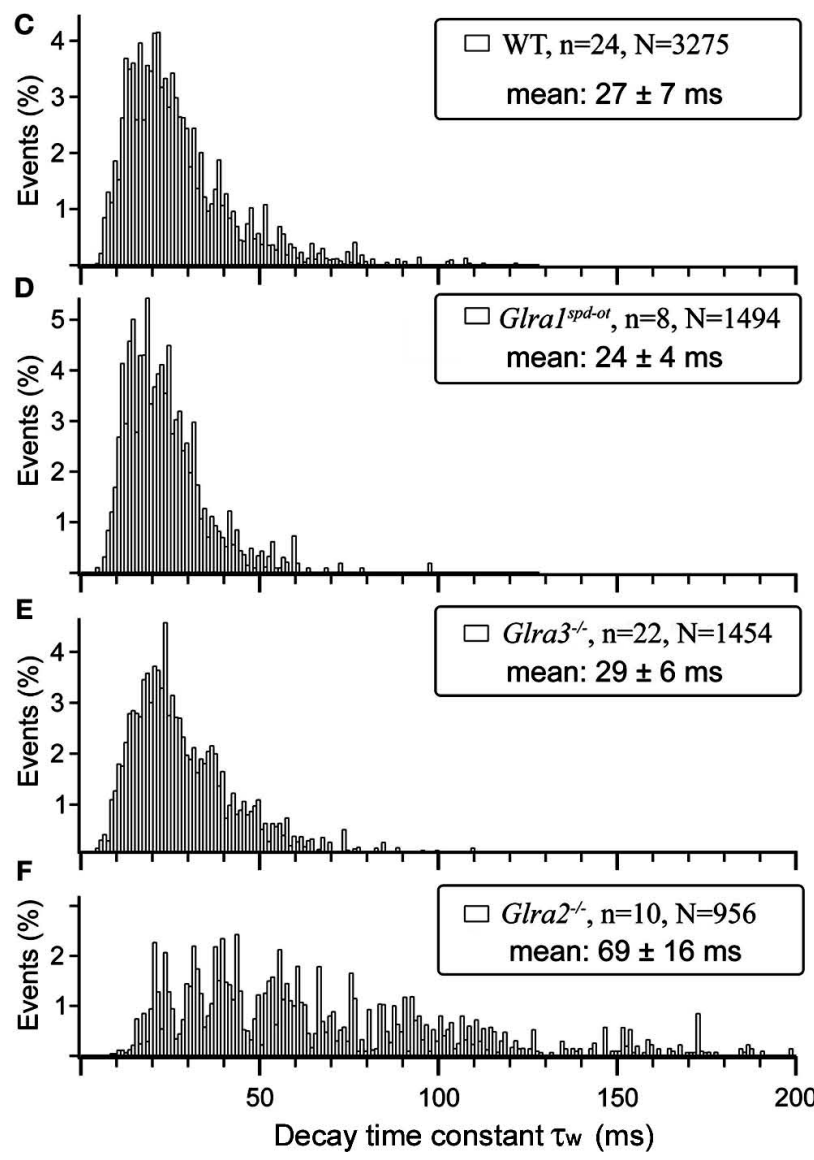

in wild-type mice (black histogram). The brown histogram shows the sIPSCs recorded from NF cells in wild-type mice. (C) Decay time constants $\tau_{w} s$ of glycinergic sIPSCs recorded from NF amacrine cells of wild-type mice. (D) $\tau_{w} s$

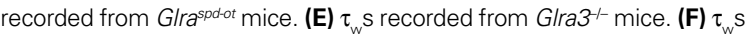
recorded from Glra2 ${ }^{-1-}$ mice. 
of picrotoxinin to $73.6 \pm 1.8 \%$ in AII cells and to $69.9 \pm 1.8 \%$ in NF cells. Glycine-induced currents were also measured in Glra1 ${ }^{\text {spd-ot }}$, Glra2 $^{-l-}$ (Weiss et al., 2008) and Glra3 $^{-l-}$ mouse retina. Comparable to $\mathrm{Glra3}^{-/-}$mice, no obvious phenotype was observed in Glra2 $2^{-/-}$ mice (Weiss et al., 2008; Young-Pearse et al., 2006). In the case of $\mathrm{NF}$ amacrine cells the currents elicited in the three mutant mouse lines were not different from those measured in wild-type mice. In AII amacrine cells the currents were significantly reduced in Glra3 $^{-1-}$ mice but not in the other two mutants.

The analysis of sIPSCs revealed significant differences between AII and NF amacrine cells (Figure 7B). Glycinergic sIPSCs recorded from AII amacrine cells could be approximated by a single decay time constant. The histogram of decay time constant $\tau$ from AII amacrine cells showed a peak at $\sim 10 \mathrm{~ms}$ and a mean of $11.2 \pm 2.0 \mathrm{~ms}$ ( $n=33 ; N=2407)$. Glycinergic sIPSCs recorded from NF amacrine cells could be approximated in $80 \%$ of the cells by a single exponential function, in $20 \%$ of the cells a bi-exponential fit had to be applied from which a single weighted decay time constant was calculated. The histogram of decay time constants $\tau_{\mathrm{w}}$ of NF amacrine cells in Figure 7C shows a peak at $\sim 20 \mathrm{~ms}$ and a mean of $27 \pm 7 \mathrm{~ms}(n=24 ; N=3275)$. The difference of the decay time constants between AII cells and NF cells was statistically significant (Weiss et al., 2008).

In order to reveal the GlyR subunits that are responsible for these differences, sIPSCs were also recorded in Glra1 ${ }^{\text {spd-ot }}, \mathrm{Glra2}^{-1-}$ and $\mathrm{Glra}^{-1-}$ mutant mice. In the case of AII cells, the decay time constants measured in wild-type, Glra1 ${ }^{\text {spd-ot }}$ and Glra2 ${ }^{-l-}$ mice were not significantly different. We also attempted to record glycinergic sIPSCs from AII cells in $\mathrm{Glra3}^{-/-}$mice, however, in a total of $n=50$ cells recorded, no glycinergic sIPSCs could be measured. This suggests that the GlyR $\alpha 3$ subunit is a necessary constituent of synaptic GlyRs on AII cells. In the case of NF cells, sIPSCs were measured in all three mutant mice (Figures 7C-F). No significant differences in the distribution of decay time constant $\tau_{\mathrm{w}}$ were observed when results from wild-type (Figure 7C), Glra1 ${ }^{\text {spd-ot }}$ (Figure 7D) and $\mathrm{Glra3}^{-/-}$(Figure 7E) mice were compared. By contrast, decay time constants measured from Glra2 ${ }^{-l-}$ mice (Figure 7F) were significantly longer. This difference was highly significant (KolmogorovSmirnov $p<0.01$ ) and suggests that the $\alpha 2$ subunit shapes the kinetics of GlyRs in NF amacrine cells.

\section{GLYCINE RECEPTORS EXPRESSED BY OTHER RETINAL NEURONS}

Glycine induced currents and sIPSCs were also recorded from displaced wide-field, putative GABAergic amacrine cells (Majumdar et al., 2009). These GlyRs had slow kinetics (mean $\tau>25$ ms; Majumdar et al., 2009; Veruki et al., 2007) comparable to NF amacrine cells. ON-starburst (cholinergic amacrine cells) had sIPSCs with extremely long decay time constants (mean $\tau \sim 70 \mathrm{~ms}$ ), which did not differ between wild-type and the three mutant mice (Majumdar et al., 2009). Since GlyR $\alpha 4$ immunoreactive puncta (Figure 3F) occur at higher density along the dendrites of ONstarburst amacrine cells, it is possible that GlyRs of ON-starburst cells are dominated by the $\alpha 4$ subunit. This would in turn suggest that GlyRs containing the $\alpha 4$ subunit have slow kinetics.

There are approximately 15 different types of ganglion cells in any mammalian retina. The GlyRs expressed by A-type ganglion cells of the mouse retina were also investigated both in wild-type and mutant mice (Majumdar et al., 2007). In the wild-type retina, glycinergic sIPSCs of A-type ganglion cells have fast kinetics (mean $\tau=3.9 \pm 2.5 \mathrm{~ms}$ ). Glycinergic sIPSCs recorded from $\mathrm{Glra}^{-1-}$ and $\mathrm{Glra3}^{-1-}$ mice did not differ from those of wild-type mice. However, the number of glycinergic sIPSCs was significantly reduced in Glra1 $1^{\text {spd-ot }}$ mice and the remaining sIPSCs had slower kinetics. These results show that A-type ganglion cells receive preferentially kinetically fast glycinergic inputs, mediated by GlyRs containing $\alpha 1$ subunits.

\section{DISCUSSION}

All four GlyR $\alpha$ subunits are clustered in synaptic hot spots (Figure 3) that show characteristic distributions across the IPL of the mouse retina (Heinze et al., 2007). Gephyrin is responsible for clustering GlyRs to postsynaptic sites by linking the GlyR $\beta$ subunit to the cytoskeleton (Kirsch et al., 1993; Vannier and Triller, 1997). In gephyrin deficient mouse retinas no GlyR clusters could be detected (Fischer et al., 2000) which suggests that synaptic GlyRs in the retina are always heteromeric, i.e. composed of $\alpha$ and $\beta$ subunits. In the adult, two copies of the $\alpha$ subunit and three copies of the $\beta$ subunit form the pentameric receptor protein (Grudzinska et al., 2005). Thus, it is theoretically possible that two different $\alpha$ subunits are present in a heteromeric GlyR. From double-labelling experiments using subunit-specific antibodies we found that - as a rule- only one type of $\alpha$ subunit is present in a given receptor. However, colocalization of two GlyR $\alpha$ subunits within the same synaptic cluster has also been observed. In the case of the GlyR $\alpha 2$ and GlyR $\alpha 3$ subunits we found a coincidence rate of $26.7 \%$ (Haverkamp et al., 2004), whilst in the case of GlyR $\alpha 2$ and GlyR $\alpha 4$ subunits $31.5 \%$ of the GlyR $\alpha 4$ clusters also contained GlyR $\alpha 2$ (Heinze et al., 2007).

To date, selective agonists or antagonists that distinguish different isoforms of synaptic GlyRs have not been identified (Betz and Laube, 2006; Harvey and Betz, 2000; Legendre, 2001; Lynch, 2004). However, mutant mice with specific knockouts or spontaneous mutations of GlyR $\alpha 1, \alpha 2$ or $\alpha 3$ subunit genes have proven to be useful tools for the analysis of GlyRs expressed by different retinal neurons. If a given retinal cell type expresses exclusively $\alpha 1 \beta, \alpha 2 \beta$ or $\alpha 3 \beta$ synaptic receptors, one would imagine that both glycine-induced currents and glycinergic sIPSCs should be abolished in the corresponding mutant which is the case for bipolar cells of Glra1 ${ }^{\text {spd-ot }}$ mice. However, the situation is usually more complex, because given retinal neurons express more than one type of synaptic GlyR (Majumdar et al., 2007, 2009; Weiss et al., 2008). These synaptic receptors might be localised at the same postsynaptic site and small glycine-containing vesicles released from the presynaptic terminal could activate both receptors simultaneously. Hence the sIPSC will be composed of the pooled responses of both receptors. However, it is also possible that GlyRs are composed of $\alpha 2 \alpha 3 \beta$ or $\alpha 2 \alpha 4 \beta$ subunits and such receptors may have unusual and characteristic kinetics. Moreover, there may be a compensatory up-regulation of expression of other GlyR subunit genes, ameliorating the loss of the subunit affected by the knockout/ mutation (Heinze et al., 2007). Keeping these provisos in mind, GlyRs of the mammalian retina have the following properties:

The GlyR $\alpha 1$ subunit is clustered in large synaptic hot spots in the OFF-sublamina (Figure 3A), which represent synapses from AII amacrine cells onto OFF-bipolar cell axon terminals (SassoèPognetto et al., 1994). GlyR $\alpha 1$ immunoreactive puncta in the inner IPL (Figures 3A and 5B) are located on ganglion cell dendrites 
(Majumdar et al., 2007). Rod bipolar cells receive input along their axons descending through the IPL, while their axon terminals do not coincide with GlyR $\alpha 1$ hot spots (Ivanova et al., 2006). Studies with recombinant GlyRs have shown that the expression of the GlyR $\alpha 1$ subunit results in channels with fast kinetics (Betz and Laube, 2006; Harvey et al., 2000; Legendre, 2001; Lynch, 2004). This is consistent with GlyR-mediated synaptic currents (sIPSCs) recorded from the adult brain stem, where GlyR $\alpha 1$-containing synapses show a fast decay time constant ( $\tau \sim 6 \mathrm{~ms}$; Singer et al., 1998). OFF-cone bipolar, rod bipolar and A-type ganglion cells of the retina have GlyR $\alpha 1$-containing synapses which also have fast decay time constants ( $\tau$ bip $\sim 5.9 \mathrm{~ms}, \tau$ gang $\sim 3.9 \mathrm{~ms}$; Ivanova et al., 2006; Majumdar et al., 2007).

GlyR $\alpha 2$ immunoreactive synapses (Figure 3D) are distributed more evenly across the IPL and are the most frequent type of glycinergic synapses in this region (Haverkamp et al., 2004). GlyR $\alpha 2$ is not expressed by bipolar cells (Ivanova et al., 2006), but is confined to amacrine and ganglion cells. Since in the neonatal brain stem and spinal cord GlyR $\alpha 2$ is the predominant subunit (Becker et al., 1988; Malosio et al., 1991; Singer et al., 1998; Smith et al., 2000; Takahashi et al., 1992) it was possible to study the kinetics of synapses containing $\alpha 2$ GlyRs. Spontaneous IPSCs recorded from neonatal GlyRs had slow decay time constants ( $\tau \sim 14 \mathrm{~ms}$; Singer et al., 1998). In the retina, narrow-field (NF) amacrine cells receive their predominant glycinergic input through synapses containing GlyR $\alpha 2$ (Figure 7) and spontaneous IPSCs recorded from these synapses also have slow decay time constants $(\tau \sim 27 \mathrm{~ms}$ ). A-type ganglion cells (Majumdar et al., 2007) also received a small portion of their glycinergic input through synapses expressing GlyR $\alpha 2$. This was demonstrated both by physiological recordings and immunostaining. In other ganglion cell classes this input through GlyR $\alpha 2$ expressing synapses was more prominent (Majumdar, unpublished results).

GlyR $\alpha 3$ expressing synapses have been described in the dorsal horn of the spinal cord (Harvey et al., 2004), but their kinetic parameters are not yet known in detail (Heindl et al., 2007). Synapses containing GlyR $\alpha 3$ in the mouse retina are aggregated in four sublayers of the IPL (Figure 3E) and their density is reduced along the two sublayers where the dendrites of starburst amacrine cells are found. It was found that dendrites of AII amacrine cells in sublamina 1/2 express GlyR $\alpha 3$ immunoreactive puncta (Haverkamp et al., 2003). Haverkamp et al. (2003) observed also GlyR $\alpha 3$ immunoreactive puncta on the axon terminals of OFF-cone bipolar cells. The physiological results, however, did not confirm a glycinergic input of cone bipolar cells that would be mediated by the GlyR $\alpha 3$ subunit (Ivanova et al., 2006). It is, therefore, possible that the GlyR $\alpha 3$ labeled puncta were not localized on the bipolar cell axon terminals but on nearby amacrine cells processes. A-type ganglion cells too expressed GlyR $\alpha 3$ immunoreactive puncta along their dendrites (Majumdar et al., 2007). Physiological recordings have shown that AII amacrine cells have glycinergic synapses containing the GlyR $\alpha 3$ subunit (Weiss et al., 2008). Spontaneous IPSCs recorded from AII cells had decay time constants $(\tau \sim 11 \mathrm{~ms})$ which were slower than those of synapses containing GlyR $\alpha 1$ but faster than those harbouring GlyR $\alpha 2$. In the rat retina sIPSCs of AII amacrine cells also exhibited fast kinetics (Gill et al., 2006).

To date, synapses containing GlyR $\alpha 4$ have only been described in the mammalian retina (Heinze et al., 2007). They are sparsely distributed across the IPL with a significantly higher density within the sublamina where the processes of ON-starburst amacrine cells ramify. Double labeling experiments with antibodies against choline acetyltransferase and GlyR $\alpha 4$ suggested that processes of ON-starburst cells express GlyR $\alpha 4$ in synaptic hot spots (Heinze et al., 2007). The kinetics of sIPSCs of synapses containing GlyR $\alpha 4$ can only be estimated from circumstantial evidence. As mentioned above, sIPSCs of NF amacrine cells receive their predominant glycinergic input through synapses harbouring GlyR $\alpha 2$. However, in the Glra2 ${ }^{-1-}$ mouse NF amacrine cells still received a small number of slow glycinergic sIPSCs, which are most likely to represent synapses containing GlyR $\alpha 4$ (Figure 7F). The decay time constants of these slow sIPSCs $(\tau \sim 70 \mathrm{~ms})$ were much slower than those recorded from synapses containing GlyR $\alpha 2$ (Weiss et al., 2008). Recent recordings of glycinergic sIPSCs from ON-starburst cells which are decorated by GlyR $\alpha 4$ immunoreactive puncta have shown that GlyRs of ON-starburst cells in $\mathrm{Glra2}^{-1-}$ mice also have slow kinetics $(\tau \sim 70 \mathrm{~ms})$. Although they did not differ between wild-type, GlyR $\alpha 1$, and GlyR $\alpha 3$ subunit mutant mice, the final proof that such slow GlyRs contain the $\alpha 4$ subunit will require the generation of $\mathrm{Glra4}^{-1-}$ mice.

In conclusion, more insights into the functional role of GlyRs in retinal processing can only come from measurements of light responses. Early experiments in the intact cat eye, involving extracellular recordings from ganglion cells and iontophoretic application of glycine and its antagonist strychnine, showed that the light responses of all ganglion cells become more sustained upon the application of strychnine (Bolz et al., 1985). With the same approach it was shown that in the dark adapted retina light responses of OFF-ganglion cells were completely blocked by the application of strychnine (Müller et al., 1988). This confirms that the signal transfer from AII amacrine cells to OFF-cone bipolar cells involves a glycinergic synapse. More recently light responses were studied in retinal slices and retinal whole mounts. Recordings from mouse rod bipolar cells showed that they receive three light driven inhibitory inputs: a fast input mediated by $\mathrm{GABA}_{\mathrm{A}}$ receptors, an intermediate input through GlyRs and a slow input through $\mathrm{GABA}_{\mathrm{C}}$ receptors (Eggers and Lukasiewicz, 2006). Modulating the relative proportions of these inhibitory inputs will change the characteristics of rod bipolar cell output. Recordings from A-type ganglion cells of the mouse retina (Manookin et al., 2008; Murphy and Rieke, 2008; van Wyk et al., 2009) demonstrated that the light driven responses of OFF-A type ganglion cells were mediated by direct glycinergic inhibitory inputs. The light responses of local edge detector (LED) ganglion cells of the rabbit retina are dominated by inhibitory inputs mediated by glycinergic amacrine cells (van Wyk et al., 2006). These examples show that glycinergic inhibition not only modulates the light responses of retinal neurons but it is also instrumental for creating specificity, preferentially by crossover inhibition between the $\mathrm{ON}$ - and the OFF-channels.

\section{ACKNOWLEDGEMENTS}

We are grateful to Dr. Ulrike Müller, Dr. G. A. O’Sullivan and Dr. Heinrich Betz for providing the $\mathrm{Glra3}^{-/-}$and the $\mathrm{Glra}^{---}$mice, respectively. We thank Brigitte Marshallsay and Brigitte Sinke for excellent technical assistance and Irmgard Odenthal for typing the manuscript. 


\section{REFERENCES}

Badea, T. C., and Nathans, J. (2004). Quantitative analysis of neuronal morphologies in the mouse retina visualized by using a genetically directed reporter. J. Comp. Neurol. 480, 331-351.

Becker, C.-M., Hoch, W., and Betz, H. (1988). Glycine receptor heterogeneity in rat spinal-cord during postnatal-development. EMBO J. 7, 3717-3726.

Betz, H., and Laube, B. (2006). Glycine receptors: recent insights into their structural organization and functional diversity. J. Neurochem. 97, 1600-1610.

Bolz, J., Their, P., Voigt, T., and Wässle, H. (1985). Action and localization of glycine and taurine in the cat retina. J. Physiol. 362, 395-413.

Buckwalter, M. S., Cook, S. A., Davisson, M. T., White, W. F., and Camper, S. A., (1994). A frameshift mutation in the mouse $\alpha 1$ glycine receptor gene (Glral) results in progressive neurological symptoms and juvenile death. Hum. Mol. Genet. 3, 2025-2030.

Eggers, E. D., and Lukasiewicz, P. D. (2006). Receptor and transmitter release properties set the time course of retinal inhibition. J. Neurosci. 26, 9413-9425.

Ehinger, B., and Falck, B. (1971). Autoradiography of some suspected neurotransmitter substances: GABA, glycine, glutamic acid, histamine, dopamine, and L-DOPA. Brain Res. $33,157-172$.

Feng, G., Mellor, R. H., Bernstein, M., Keller-Peck, C., Nguyen, Q. T., Wallace, M., Nervonne, J. M., Lichtman, J. W., and Sanes, J. R. (2000). Imaging neuronal subsets in transgenic mice expressing multiple spectral variants of GFP. Neuron 28 , 41-51.

Fischer, F., Kneussel, M., Tintrup, H., Haverkamp, S., Rauen, T., Betz, H., and Wässle, H. (2000). Reduced synaptic clustering of GABA and glycine receptors in the retina of the gephyrin null mutant mouse. J. Comp. Neurol. 427, 634-648.

Flores-Herr, N., Protti, D. A., and Wässle, H. (2001). Synaptic currents generating the inhibitory surround of ganglion cells in the mammalian retina. J. Neurosci. 21, 4852-4863.

Gill, S. B., Veruki, M. L., and Hartveit, E. (2006). Functional properties of spontaneous IPSCs and glycine receptors in rod amacrine (AII) cells in the rat retina. J. Physiol. 575.3, 739-759.

Grudzinska, J., Schemm, R., Haeger, S., Nicke, A., Schmalzing, G., Betz, H., and Laube, B. (2005). The beta subunit determines the ligand binding prop- erties of synaptic glycine receptors. Neuron 45, 727-739.

Han, Y., Li, P., and Slaughter, M. M. (2003) Selective antagonism of rat inhibitory glycine receptor subunits. J. Physiol. 554.3, 649-658.

Harvey, R. J., and Betz, H. (2000). Structure, diversity, pharmacology, and pathology of glycine receptor chloride channels. In Pharmacology of Ionic Channel Function: Activators and Inhibitors, M. Endo, Y. Kurachi, and M. Mishina, eds (Heidelberg, Springer), pp. 479-497.

Harvey, R. J., Depner, U. B., Wässle, H., Ahmadi, S., Heindl, C., Reinold, H., Smart, T. G., Harvey, K., Schutz, B., Abo-Salem, O. M., Zimmer, A., Poisbeau, P., Weltzl, H., Wolfer, D. P., Betz, H., Zeilhofer, H. U., and Müller, U. (2004). GlyR $\alpha 3$ : an essential target for spinal $\mathrm{PGE}_{2}$-mediated inflammatory pain sensitization. Science 304, 884-887.

Harvey, R. J., Schmieden, V., von Holst, A., Laube, B., Rohrer, H., and Betz, H. (2000). Glycine receptors containing the $\alpha 4$ subunit in the embryonic sympathetic nervous system, spinal cord and male genital ridge. Eur. J. Neurosci. 12, 994-1001.

Haverkamp, S., Inta, D., Monyer, H., and Wässle, H. (2009). Expression analysis of green fluorescent protein in retinal neurons of four transgenic mouse lines. Neuroscience 160, 126-139.

Haverkamp, S., Müller, U., Harvey, K., Harvey R. J., Betz, H., and Wässle, H. (2003). Diversity of glycine receptors in the mouse retina: localization of the $\alpha 3$ subunit. J. Comp. Neurol. 465 , 524-539.

Haverkamp, S., Müller, U.,Zeilhofer, H. U., Harvey, R. J., and Wässle, H. (2004). Diversity of glycine receptors in the mouse retina: localization of the $\alpha 2$ subunit. J. Comp. Neurol. 477, 399-411.

Haverkamp, S., and Wässle, H. (2000). Immunocytochemical analysis of the mouse retina. J. Comp. Neurol. 424, $1-23$.

Heindl, C., Brune, K., Renner, B. (2007). Kinetics and functional characterization of the glycine receptor $\alpha 2$ and $\alpha 3$ subunit. Neurosci. Lett. 429, 59-63.

Heinze, L., Harvey, R. J., Haverkamp, S., and Wässle, H. (2007). Diversity of glycine receptors in the mouse retina: localization of the $\alpha 4$ subunit.J. Comp. Neurol. 500, 693-707.

Hsueh,H.-A.,Molnar,A., and Werblin, F. S. (2008). Amacrine-to-amacrine cell inhibition in the rabbit retina. J. Neurophysiol. 100, 2077-2088.

Ivanova, E., Müller, U., and Wässle, H. (2006). Characterization of the glycinergic input to bipolar cells of the mouse retina. Eur. J. Neurosci. 23 , 350-364.

Jusuf,P.R., Haverkamp,S., and Grünert, U. (2005).Localization of glycine receptor alpha subunits on bipolar and amacrine cells in primate retina. J. Comp. Neurol. 488, 113-128.

Kirsch, J., Wolters, I., Triller, A., and Betz, H. (1993). Gephyrin antisense oligonucleotides prevent glycine receptor clustering in spinal neurons. Nature 366, 745-748.

Kling, C., Koch, M., Saul, B., and Becker, C.-M. (1997). The frameshift mutation oscillator (Glral $\left.{ }^{\text {spd-ot }}\right)$ produces a complete loss of glycine receptor alpha1-polypeptide in mouse central nervous system. J. Neurosci. 78, 411-417.

Kolb, H., and Famiglietti, E.V. (1974). Rod and cone pathways in the inner plexiform layer of the cat retina. Science 186, 47-49.

Kolb, H., Nelson, R., and Mariani, A. (1981). Amacrine cells, bipolar cells and ganglion cells of the cat retina: a golgi study. Vision Res. 21 , 1081-1114.

Kolb, H., and West, R. W. (1977). Synaptic connections of the interplexiform cell in the retina of the cat. J. Neurocytol. 6, 155-170.

Legendre, P. (2001). The glycinergic inhibitory synapse. Cell. Mol. Life Sci. $58,760-793$.

Lin, B., and Masland, R. H. (2006). Populations of wide-field amacrine cells in the mouse retina. J. Comp. Neurol. 499, 797-809.

Lynch, J. W. (2004). Molecular structure and function of the glycine receptor chloride channel. Physiol. Rev. 84 1051-1095.

MacNeil, M. A., and Masland, R. H. (1998). Extreme diversity among amacrine cells, implications for function Neuron 20, 971-982.

Majumdar, S., Heinze, L., Haverkamp, S. Ivanova, E. and Wässle, H. (2007). Glycine receptors of A-type ganglion cells of the mouse retina. Vis. Neurosit. 24, 1-17.

Majumdar, S., Weiss, J., and Wässle, H. (2009). Glycinergic input of widefield, displaced amacrine cells of the mouse retina. J. Physiol. (in press).

Malosio, M. L., Marqueze-Pouey, B., Kuhse, J., and Betz, H., (1991). Widespread expression of glycine receptor subunit mRNAs in the adult and developing rat brain. $E M B O J .10$ 2401-2409.

Manookin, M. B., Beaudoin, D. L., Ernst, Z. R., Flagel, L. J., and Demb, J. B. (2008). Disinhibition combines with excitation to extend the operating range of the OFF visual pathway in daylight. J. Neurosci. 27, 5994-6005.
Marc, R. E. (1989). The role of glycine in the mammalian retina. Prog. Retin. Res. 8, 67-107.

Marc, R.E., and Liu, W.-L.S. (1985). (3H) Glycine-accumulating neurons of the human retina. J. Comp. Neurol. 232, 241-260.

Masland, R. H. (2001). The fundamental plan of the retina. Nat. Neurosci. 4 , 877-886.

Menger, N., Pow, D. V., and Wässle, H. (1998). Glycinergic amacrine cells of the rat retina. J. Comp. Neurol. 401, 34-46.

Müller, F., Wässle, H., and Voigt, T. (1988). Pharmacological modulation of the rod pathway in the cat retina. J. Neurophysiol. 59, 1657-1672.

Murphy, G. J., and Rieke, F. (2008). Signals and noise in an inhibitory interneuron diverge to control activity in nearby retinal ganglion cells. Nat Neurosci. $11,318-326$.

Pourcho, R. G. (1980). Uptake of $\left[{ }^{3} \mathrm{H}\right]$ glycine and $\left[{ }^{3} \mathrm{H}\right] \mathrm{GABA}$ by amacrine cells in the cat retina. Brain Res. 198, 333-346.

Pourcho, R. G. (1996). Neurotransmitters in the retina. Curr. Eye Res. 15, 797-803.

Pourcho, R. G., and Goebel, D. J. (1985). A combined Golgi and autoradiographic study of $\left[{ }^{3} \mathrm{H}\right]$ glycine-accumulating amacrine cells in the cat retina. J. Comp. Neurol. 233, 473-480.

Pourcho, R. G., and Owczarzak, M. T. (1991a). Connectivity of glycine immunoreactive amacrine cells in the cat retina. J. Comp. Neurol. 307, 549-561.

Pourcho, R. G., and Owczarzak, M. T. (1991b). Glycine receptor immunoreactivity is localized at amacrine synapses in cat retina. Vis. Neurosci. 7, 611-618.

Pow, D. V. (1998). Transport is the primary determinant of glycine content in retinal neurons. J. Neurochem. 70 , 2628-2636.

Pow, D. V., and Hendrickson, A. (1999). Distribution of the glycine transporter GlyT-1 in mammalian and nonmammalian retinae. Vis. Neurosci. 16, 231-239.

Pow, D. V., and Hendrickson, A. (2000). Expression of glycine and the glycine transporter GlyT-1 in the developing rat retina. Vis. Neurosci. 17, 1-9.

Pribilla, I., Takagi, T., Langosch, D., Bormann, J., and Betz, H. (1992). The atypical M2 segment of the $\beta$ subunit confers picrotoxinin resistance to inhibitory glycine receptor channels. EMBO J. 11, 4305-4311.

Sassoè-Pognetto, M., Wässle, H., and Grünert, U. (1994). Glycinergic synapses in the rod pathway of the rat retina: cone bipolar cells express the $\alpha 1$ subunit of the glycine receptor. J. Neurosci. 14, 5131-5146. 
Singer, J. H., Talley, E. M., Bayliss, D. A., and Berger, A. J. (1998). Development of glycinergic synaptic transmission to rat brain stem motoneurons. J. Neurophysiol. 80, 2608-2620.

Smith, A. J., Owens, S., and Forsythe, I. D. (2000). Characterisation of inhibitory and excitatory postsynaptic currents of the rat medial superior olive. J. Physiol. 529, 681-698.

Takahashi, T., Momiyama, A., Hirai, K., Hishinuma, F., and Akagi, H. (1992). Functional correlation of fetal and adult forms of glycine receptors with developmental changes in inhibitory synaptic receptor channels. Neuron 9 , 1155-1161.

Taylor, W. R., and Vaney, D. I. (2003). New directions in retinal research. Trends in Neurosci. 26, 379-385.

Vaney, D. I. (1990). The mosaic of amacrine cells in the mammalian retina. Prog. Retin. Res. 9, 40-100.

Vaney, D. I., Nelson, J. C., and Pow, D. V. (1998). Neurotransmitter coupling through gap junctions in the retina. J. Neurosci. 18, 10594-10602.
Vannier, C., and Triller, A. (1997). Biology of the postsynaptic glycine receptor. Int. Rev. Cytol. 176, 201-244.

van Wyk, M., Taylor, W. R., and Vaney, D. I. (2006). Local edge detectors: a substrate for fine spatial vision at low temporal frequencies in rabbit retina. J. Neurosci. 26, 13250-13263.

van Wyk, M., Wässle, H., and Taylor, W. R. (2009). Receptive field properties of ON- and OFF-ganglion cells in the mouse retina. Visual Neurosci. (in press).

Veruki, M. L., Gill, S. B. and Hartveit, E. (2007). Spontaneous IPSCs and glycine receptors with slow kinetics in wide-field amacrine cells in the mature rat retina. J. Physiol. 581, 203-219.

Wässle, H. (2004). Parallel processing in the mammalian retina. Nat. Rev. Neurosci. 5, 747-757.

Wässle, H., Puller, C., Müller, F., and Haverkamp, S. (2009). Cone contacts, mosaics, and territories of bipolar cells in the mouse retina. J. Neurosci. 29, 106-117.
Wässle, H., Schäfer-Trenkler, I., and Voigt, T. (1986). Analysis of a glycinergic inhibitory pathway in the cat retina. J. Neurosci. 6, 594-604.

Wang, P. Y., and Slaughter, M. M. (2005). Effects of GABA receptor antagonists on retinal glycine receptors and on homomeric glycine receptor alpha subunits. J. Neurophysiol. 93 , 3120-3126.

Weiss, J., O’Sullivan, G. A., Heinze, L. Chen, H.-X., Betz, H., and Wässle, $\mathrm{H}$ (2008). Glycinergic input of smallfield amacrine cells in the retinas of wild type and glycine receptor deficient mice. Mol. Cell. Neurosci. 37 , 40-55.

Young-Pearse, T. L., Ivic, L., Kriegstein, A. R., and Cepko, C. L. (2006). Characterization of mice with targeted deletion of glycine receptor alpha 2. Mol. Cell. Biol. 26, 5728-5734.

Zafra, F., Aragon, C., Olivares, L., Danbolt, N. C., Gimenez, C., and Storm-Mathisen, J. (1995). Glycine transporters are differentially expressed among CNS cells. J. Neurosci. $15,3952-3969$.

Conflict of Interest Statement: The authors declare that the research was conducted in the absence of any commercial or financial relationships that could be construed as a potential conflict of interest.

Received: 11 May 2009; paperpending published: 02 June 2009; accepted: 21 June 2009; published online: 09 July 2009.

Citation: Wässle H, Heinze L, Ivanova E, Majumdar S, Weiss J, Harvey RJ and Haverkamp S (2009) Glycinergic transmission in the mammalian retina. Front. Mol. Neurosci. (2009) 2:6. doi:10.3389/neuro.02.006.2009

Copyright (c) 2009 Wässle, Heinze, Ivanova, Majumdar, Weiss, Harvey and Haverkamp. This is an open-access article subject to an exclusive license agreement between the authors and the Frontiers Research Foundation, which permits unrestricted use, distribution, and reproduction in any medium, provided the original authors and source are credited. 